inOedia $\quad \begin{aligned} & \text { InMedia } \\ & \text { The French Journal of Media Studies }\end{aligned}$

$1 \mid 2012$

Global Film and Television Industries Today

\title{
Alexis Blanchet, Des Pixels à Hollywood. Cinéma et jeu vidéo, une histoire économique et culturelle
}

Joël Augros

Translator. Thibaut Clément

OpenEdition

Journals

Electronic version

URL: http://journals.openedition.org/inmedia/148

DOI: 10.4000/inmedia.148

ISSN: 2259-4728

Publisher

Center for Research on the English-Speaking World (CREW)

Electronic reference

Joël Augros, "Alexis Blanchet, Des Pixels à Hollywood. Cinéma et jeu vidéo, une histoire économique et culturelle », InMedia [Online], 1 | 2012, Online since 23 March 2012, connection on 23 September 2020 URL : http://journals.openedition.org/inmedia/148; DOI : https://doi.org/10.4000/inmedia.148

This text was automatically generated on 23 September 2020.

(C) InMedia 


\title{
Alexis Blanchet, Des Pixels à Hollywood. Cinéma et jeu vidéo, une histoire économique et culturelle
}

\author{
Joël Augros
}

Translation : Thibaut Clément

\section{REFERENCES}

Alexis Blanchet, Des Pixels à Hollywood. Cinéma et jeu vidéo, une histoire économique et culturelle, Paris : Pix'N Love Editions, 2010, 450 pages

1 Alexis Blanchet's book forms part of a larger body of research for which he was made a Doctor in Film Studies at the Université Paris Ouest Nanterre La Défense in 2009.

The text under review revolves around "how these two major players [i.e. cinema and videogames] in the field of mass entertainment have developed intermittent economic, cultural and aesthetic ties over the course of the past forty years" (p. 13). Ever since the development of videogames in the 1970s, Hollywood's major studios have developed a close interest in the industry, making Jaws the first - albeit unofficial - film-tovideogame adaptation in 1975.

3 As he writes in the opening of his book, Blanchet aims to address both avid videogame players-the so-called hardcore gamers-and students in the field of communication, journalism, or performance studies. He wishes to combine "the high standards of academic research with the ease of read of widely accessible texts" (p. 13). It is to the author's credit that he has succeeded on both counts. The text is written clearly, while displaying a thorough understanding of the industry as well as a comprehensive knowledge of pioneering research by English-speaking scholars. The author's command of the subject is most apparent in the exhaustive database presented in the book's concluding chapter, which the author playfully entitled "bonus material." 
4 The book's overall organization is chronological, which seems a wise choice for a text intended for a wide audience. Blanchet's work nevertheless manages to go beyond the purely day-to-day, anecdotal details, as his critical analysis of the history of videogames demonstrates. Each chapter provides a detailed case study which illustrates and develops the evolutions under study. Throughout the whole book, the author continuously and skillfully combines aesthetic, sociological and cultural approaches-a versatility best exemplified by his discussion of the evolution of mainstream cinema, the development of mall theaters, arcade videogames or emerging patterns of consumption (p. 117).

5 This wide encompassing approach allows the author to reach beyond obvious and expected conclusions. Rather than simply keeping track of the film-to-videogame ratio over time, Blanchet discusses the gradual convergence of the two industries through a careful analysis of cross-investment and of patterns of organization common to both sectors. He clearly shows how the structure of the videogame industry was modeled first under the influence of Hollywood majors and, from the 1990s on, by the development of the consumer electronics industry (p. 314). In the same way, Blanchet demonstrates how, in the 1970s, Hollywood majors and the toy industry both defined children as their core target, at a time when videogames were making their first foray outside amusement arcades.

6 The book, whose main argument rests on the gradual convergence of both the movie and videogame industries, does not restrict itself to the sole discussion of their mutual adaptation - a pitfall common to many other such studies - but successfully explores the subject's many ramifications. The author thus discusses the visual aesthetics of videogames, film sequences, the regional or global circulation of products, as well as the increasingly similar promotion of videogames and blockbusters, as both rely on short campaigns, while videogames now use promotional featurettes directly modeled on those found on DVDs.

7 This book is a valuable contribution to the field of videogames and mainstream cinema studies: it cleverly deconstructs both mass entertainment industries, whose structures and products are shown to closely reflect each other, despite distinct development strategies. The choice of discussing videogames with the tools originally developed for the comprehensive analysis of film - that is, considering its aesthetics, economic, sociological as well as technical aspects - allows for an extremely convincing crossdisciplinary analysis.

8 Despite minor misprints, the book is well edited and published in a convenient format with easy-to-read fonts. The tables are clear and the screenshots that complement the text are especially relevant. The book also features a useful appendix presenting the main results from the database as well as a lexicon of the most widely used terms in the industry. 


\section{AUTHORS}

JOËL AUGROS

Université Vincennes-Saint-Denis - Paris 